\title{
Manajemen Pendidikan Karakter Di Sekolah Dasar Berbasis Pendekatan Leadership $4 \mathrm{~h}$
}

\author{
Ade E. Bahtiar S \\ UIN Sunan Gunung Djati Bandung, Indonesia \\ Email: Adebach214@gmail.com
}

\begin{abstract}
education management which uses an approach called 4H Leadership. By adapting this approach, some facts show a good development in the character education of students, but on the other hand many problems arise in the three aspects mentioned above which are an important focus in educational management so that they become a concern in this research. This study aims to get an overall picture of the real activities of the implementation of character education management in elementary schools, which include planning, organizing, implementing, evaluating, as well as the results that have been achieved from the implementation of character education based on the 4H Leadership approach in SD Cendekia Leadership School. In this study a qualitative method was conducted using interview techniques, documentation studies, and observations and re-examinations to obtain complete and accurate information. The findings obtained during the study include a general description that the SD Scholar Leadership School has implemented character education management which includes planning, implementing, and evaluating systematically based on adequate management principles. The $4 \mathrm{H}$ Leadership Approach is one approach that can be relied upon to be applied in character education in primary schools even though it requires adequate resources and facilities. The implementation of character education in elementary schools is the right time and is a must for the education world to manage it properly.
\end{abstract}

Keywords : Management, Education, leadership

\begin{abstract}
ABSTRAK
pengelolaan pendidikan yang menggunakan sebuah pendekatan yang disebut Leadership $4 H$. Dengan mengadaptasikan pendekatan tersebut, beberapa fakta menunjukkan adanya perkembangan yang baik dalam pendidikan karakter siswa, namun disisi lain banyak masalah-masalah timbul dalam ketiga aspek tersebut di atas yang menjadi fokus penting dalam manajemen pendidikan sehingga menjadi perhatian dalam penelitian ini. Penelitian ini bertujuan untuk mendapatkan gambaran secara keseluruhan mengenai kegiatan nyata dari pelaksanaan manajemen pendidikan karakter di sekolah dasar, yakni meliputi perencanaan, pengorganisasian, pelaksanaan, evaluasi, serta hasil yang sudah dicapai dari implementasi pendidikan karakter berbasis pendekatan Leadership 4H di SD Cendekia Leadership School. Dalam penelitian ini dilakukan metode kualitatif dengan teknik wawancara, studi dokumentasi, dan observasi serta pemeriksaan ulang untuk mendapatkan informasi yang lengkap dan akurat. Adapun temuan-temuan yang diperoleh selama penelitian adalah meliputi gambaran umum bahwa SD Cendekia Leadership School sudah melaksanakan manajemen pendidikan karakter yang meliputi perencanaan, implementasi, dan evaluasi secara sistematis berdasarkan kaidah manajemen yang memadai. Pendekatan Leadership $4 H$ merupakan salah satu pendekatan yang dapat diandalkan untuk diaplikasikan dalam pendidikan karakter di sekolah dasar meski memerlukan sumber daya dan sarana yang memadai. Pelaksanaan pendidikan karakter di sekolah dasar adalah masa yang tepat serta menjadi keharusan bagi dunia pendidikan untuk mengelolanya dengan benar.
\end{abstract}

Kata Kunci : Manajemen, Pendidikan, kepemimpinan 


\section{PENDAHULUAN}

Pendidikan sebagai proses pendewasaan yang dilakukan oleh orang dewasa, yakni orang tua dan guru terhadap orang yang belum dewasa, yakni anak-anak, peserta didik dianggap belum berhasil secara optimal di Indonesia. Marzuki mengatakan bahwa pendidikan di Indonesia hingga sekarang masih menyisakan banyak persoalan, baik dari segi kurikulum, manajemen, maupun para pelaku dan pengguna Pendidikan (Marzuki, 2015). Artinya bahwa pendidikan belum berfungsi dengan benar sesuai dengan amanat Undang-Undang Republik Indonesia tentang Sistem Pendidikan Nasional Nomor 20 Tahun 2003 Bab II, Pasal 3, dimana fungsi pendidikan untuk membentuk watak, mencerdaskan, mengembangkan potensi dengan tujuan menjadikan manusia beriman, berilmu, cakap, kreatif, mandiri, demokratis, dan bertanggungjawab.(AA, 2011)

Sekolah sebagai lingkungan kedua yang menjadi andalan dalam proses pendidikan terus berbenah diri untuk memfasilitasi lebih lengkap dalam pendewasaan ini untuk membekali para peserta didik, selain dengan ilmu pengetahuan dan keterampilan juga yang lebih utama dengan penanaman nilai-nilai spiritual, budi pekerti atau ahlak dengan berbasis minat dan bakat yang sudah Allah SWT anugerahkan bagi setiap manusia. Namun demikian, upaya-upaya yang sudah dilakukan oleh semua sekolah di Indonesia masih banyak mengalami hambatan bahkan nyaris dianggap mengalami kegagalan, sebagaimana dinyatakan oleh Haitami Salim dalam Syamsul Kurniawan dimana pendidikan tersebut belum merepresentasikan hasil-hasil yang diharapkan, bahkan menunjukkan gejala kemerosotan moral yang amat parah, mulai dari kasus narkoba, korupsi, ketidakadilan hukum, pergaulan bebas di kalangan remaja, pelajar bahkan mahasiswa, maraknya kekerasan, kerusuhan, tindakan anarkistis, dan lain-lain yang mengindikasikan adanya pergeseran ketidakpastian jati diri dan karakter bangsa.

Demikian pula dengan proses penidikan karakter di SD Cendekia Leadership School yang sudah berupaya mengimplementasikan manajemen pendidikan karakter berbasis Leadership $4 H$ dalam kurun waktu lebih dari sepuluh tahun, namun masih ditemukan masalah-masalah yang harus dicari penyelesaiannya. Masalah-masalah tersebut memungkinkan bersumber dan saling berkaitan dalam beberapa komponen besar manajemennya yakni sekolah itu sendiri sebagai ruang atau tempat pendidikan, pendekatan leadership $4 H$ sebagai basis dalam pengelolaan pendidikan karakter para guru sebagai fasilitator pendidikan dan pengajaran, dan peserta didik itu sendiri sebagai input dan output pendidikan di sekolah tersebut (Badrudin, 2014).

Dilihat dari keadaan keseluruhan proses keseharian dalam pelaksanaan pendidikan, meskipun secara umum terlihat berhasil dalam mengimplementasikan pendidikan karakter, namun masih banyak ditemukan masalah-masalah yang berkaitan dengan tindakan-tindakan yang tidak sesuai dengan proses dan indikator pencapaian yang diorientasikan kepada tujuan profil dalam Leadership $4 H$ (Muhammad, 2015). Berikut beberapa contoh masalah yang dapat dikemukakan dari beberapa faktor sebagai berikut:

Faktor guru, Dalam keseharian pengamatan dan melihat data dari kartu absensi merk Amano ditemukan bahwa beberapa guru, yang memiliki peran sebagai teladan bagi peserta didik, masih sering terlambat datang ke sekolah, baik dengan izin atau tanpa izin. Kemudian beberapa guru lainnya atau termasuk orang yang sama sering pula meminta izin meninggalkan sekolah saat pelajaran meskipun dirinya tidak sedang mengajar. Ada pula beberapa yang meminta izin untuk tidak masuk sekolah hampir setiap minggu, bahkan terdapat pula beberapa guru yang tidak masuk tanpa izin. Selain itu, dalam aspek pengajaran, ada indikasi bahwa sebagian guru terlambat dan sangat terlambat dalam menyiapkan Rencana Pengajaran, serta ditemukan pula beberapa guru yang masih belum proporsional dalam penggunaan bahasa, baik yang menyangkut etika maupun profesi, baik pada saat berbicara dengan peserta didik maupun berbicara dengan rekan guru lainnya. Perilaku guru yang belum memiliki tanggung 
jawab tidak masuk kelas tanpa izin dan terlambat dalam membuat RPP, menunjukkan bahwa guru belum memahami nilai secara fundamental dan belum menjadi jiwa. Guru lebih banyak memaknai nilai sebagai sebuah pemahaman bukan pengalaman. Sejatinya nilai tidak bersifat lahiriah tetapi batiniah. Nilai batiniah akan muncul menjadi nilai aktual. Sedangkan nilai lahiriah masih disebut sebagai nilai potensial, karena belum tertanam secara disposisional atau laten atau belum menjadi kebiasaan yang tidak lagi diperintah secara sadar oleh pikiran. Nilai sejati atau nilai aktual berada dalam wilayah bawah sadar. Nilai tersebut sudah menjadi reflek dan bersifat otomatis. (Irawan, 2019a)

Faktor Peserta didik, Dari pengamatan keseharian terhadap perilaku peserta didik di sekolah, peneliti menemukan banyak peserta didik sering datang terlambat ke sekolah, beberapa peserta didik tidak patuh kepada peraturan sekolah. Saat pagi hari, ketika ikut menyambut kedatangan peserta didik di depan gerbang sekolah, ditemukan beberapa peserta didik yang enggan melakukan aktifitas 3S, yakni senyum, salam, dan sapa, bahkan ditemukan ada dua peserta didik yang tidak mau berjabat tangan dengan gurunya. Kemudian, mengenai kebersihan lingkungan sekolah, ditemukan masih banyakyang masih tidak peduli dengan kebersihan, baik dirinya maupun lingkungan kelas dan sekolah.

Selanjutnya, dalam hal pergaulan peserta didik, ditemukan masih ada beberapa tindakan mengganggu (bullying) di sekolah dan mengganggu di dunia maya (cyber bully) meski mereka melakukannya di rumah namun memiliki dampak kepada pergaulan di lingkungan sekolah, serta beberapa tindakan kekerasan, seperti pumukulan di kalangan para peserta didik. Beberapa kasus gangguan ditemukan pula berupa kejahilan atau iseng, seperti menyembunyikan tas teman, merobek buku catatan, dan pelaku belum dapat diketahui hingga saat ini. Dalam kaitan dengan kasus ini terdapat asumsi bahwa sebagian peserta didik masih tidak menunjukkan kejujuran dan memanipulasi fakta. Selanjutnya dalam kaitannya dengan masalah akademik, terdapat indikasi bahwa banyak para peserta didik yang mengalami motivasi belajar rendah, kurang komitmen terhadap pekerjaan mereka, dan cenderung mengabaikan.

Faktor Sekolah, Dari peninjauan keadaan sekolah, beberapa sarana dan prasarana pendukung kegiatan pendidikan sudah banyak yang dilengkapi meski ada sebagian yang belum dimiliki/terpenuhi, diantaranya sarana fisik seperti halaman sekolah yang kurang luas untuk kegiatan peserta didik. Untuk pendukung lainnya yang terkait kebijakan diantaranya adalah beberapa Prosedur Operasi Standar (Standar Operating Procedure) untuk beberapa kegiatan belum dimiliki. Kemudian, tidak memiliki Forum Orang Tua Murid dan Guru (POMG/PTA) secara resmi, artinya kegiatan komunikasi guru dan orang tua peserta didik masih efektif namun masih dilakukan secara informal. Hal lain yang ditemukan dari beberapa perbincangan dengan para orang tua, bahwa sekolah dianggap terlalu nyaman (homey school) oleh sebagian kecil orang tua peserta didik dan beberapa calon orang tua peserta didik yang berkunjung dan wawancara, sehingga ada kesan peserta didik tidak memiliki tantangan khususnya untuk belajar lebih keras. Sisi lain yang mempengaruhi proses pendidikan karakter adalah bahwa sekolah mengakomodasi Anak Berkebutuhan Khusus (ABK) yang tentunya memerlukan pemikiran dan cara khusus terkiat dengan implementasi pendidikan serta antisipasi dampak positif dan negatif dari bentuk layanan ini.

Faktor Pendekatan Leadership 4H, Dari Leadership 4H itu sendiri sebagai basis dalam pelaksanaan pendidikan karakter di Cendekia Leadership School (CLS) memiliki ranah pencapaian pendidikan yang terlalu banyak dan luas, sehingga memerlukan pemikiran dan komitmen yang kuat, sementara tidak semua guru memiliki kompetensi merata terkait dengan implementasi pendekatan tersebut. Selain itu pendekatan tersebut memerlukan soliditas dan loyalitas dari semua warga sekolah dan orang tua peserta didik dan sulit dalam pengukuran pencapiannya, serta hasil pencapaian yang terlihat belum sepenuhnya obyektif. 
Dengan demikian, peneliti ingin meneliti lebih jauh permasalahan ini guna mendapatkan manfaat yang produktif untuk berbagai pihak, khususnya demi perbaikan-perbaikan dalam implementasi pendidikan karakter, khususnya di SD Cendekia Leadership School. Adapun gambar dari pendekatan Leadership $4 H$ yang menjadi dari dalam manajemen pendidikan karakter di sekolah tersebut adalah seperti ditunjukkan dalam gambar di samping.

Gambar 1. Leadership 4H

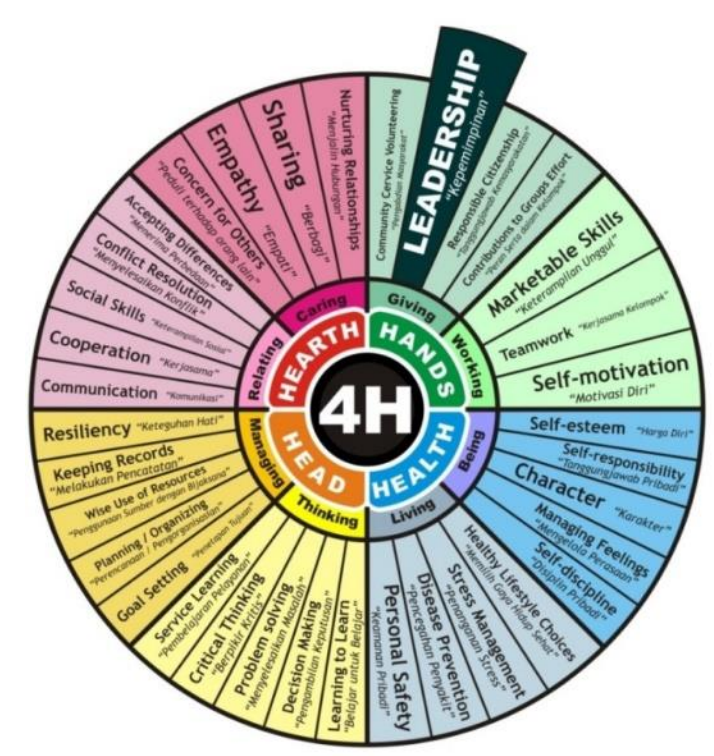

Sumber : Diolah Peneliti 2016

\section{METODE PENELITIAN}

Dalam kaitan dengan penelitian di SD CLS sebagaimana disebutkan dalam pengertian penelitian, yakni pengumpulan data, tentunya peneliti harus mempertimbangkan karakteristik penelitian dalam pendidikan dimana penelitian tersebut harus memiliki karakteristik; obyektif, tepat, sah, dapat dijelaskan, empiris, logis, dan kondisional (Terry, 2014). Selanjutnya, dengan memperhatikan tujuan penelitian maka peneliti menggunakan pendekatan penelitian yang bersifat kualitatif dimana peneliti berupaya mengeksplorasi informasi, baik yang terdapat dalam penelitian, partisipan, dan lokasi penelitian secara interaktif serta menganalisis fenomena dan makna-makna (Cresswell John W, 2014). Agar fenomena yang terjadi di lokasi penelitian terungkap apa adanya (alamiah) maka penelitian ini pun bersifat fenomenologis (Buckley, 2015).

\section{HASIL DAN PEMBAHASAN}

Perencanaan, yang dilakukan oleh SD Cendekia Leadership School dilakukan secara matang dan terorganisir serta akurat berdaarkan waktu yang sudah ditentukan dan disepakati bersama berdasarkan hasil musyawarah guru. Perencanaan tersebut memiliki orinetasi dan tujuan pencapaian kemampuan akademik dan karakter (akhlak) (Bayan, 2010) yang dalam pendekatan Leadership 4H. Selain itu perencanaan dilakukan secara hirarki dari mulai perencanaan umum yang berisi penentuan program selama satu tahun pelajaran hingga perencanaan yang bersifat khusus yang dibahas pada rapat-rapat 
tngkat kelas yang dipimpin oleh setiap Kordinator Level. Hasil perencanaan ini dibakukan sebagai panduan untuk selanjutnya disosialisasikan kepada seluruh komponen terkait agar dapat dipahami secara detail dan menyeluruh guna menghasilkan kegiatan pembelajaran yang produktif bagi siswa.

Mekanisme Pengorganisasian,Penanaman nilai-nilai karakter sebagaimana dalam leadership $4 H$ membutuhkan proses pengelolaan yang sistematis, terarah dan terawasi, penuh dengan dukungan dari semua komponen sekolah. Begitu pula dengan kondisi yang ada di CLS, seluruh komponen bekerjasama secara sistematis berdasarkan prosedur standar operasi (Standard Operating Procedure) (Munif, 2010) yang sudah disiapkan. Komponen-komponen tersebut terdiri dari Yayasan Karya Cendekia yang diwakili oleh seorang General Manager atau beberapa yayasan menyebutnya dengan Ketua Pelaksana Harian Yayasan, kemudian Kepala Sekolah atau lebih dikenal dengan sebutan Principal, School Academic Manager, yang bertanggungjawab untuk semua urusan akademik dan kepeserta didikan dan General Affair Manager yang bertanggungjawab untuk bidang sarana prasarana, hubungan masyarakat, Kordinator Unit IEP (Individual Education Program) yang memberikan layanan perkembangan akademik dan non-akademik bagi peserta didik di CLS yang dibantu dua orang psikolog, para tenaga kependidikan seperti petugas administrasi, ditambah sopir dan Satuan Pengamanan.

Untuk menciptakan suasana yang kondusif bagi upaya penanaman nilai-nilai karakter dalam Leadership 4H, seluruh komponen CLS berupaya untuk menampilkan skema keteladanan yang dijalankan Bersama (Arikunto Suahrsimi, 2014). Misalnya, larangan merokok dan merokok di area umum tentu akan menjadi sebuah tugas yang harus dikondisikan bersama sehingga peserta didik akan memahami dengan benar makna konsisten, tertib, dan disiplin. Seluruh komponen harus menerapkan nilai nilai leadership itu untuk diri masing-masing sehingga akan menjadi model bagi para peserta didik. Meski demikian, terkadang ada juga beberapa inkonsistensi dari beberapa komponen orang dewasa dalam menjalankan tugas dan fungsinya terkait dengan penanaman nilai-nilai leadership $4 \mathrm{H}$ ini.

Foto. 1 Peserta didik kls 4 CLS sedang diskusi proyek

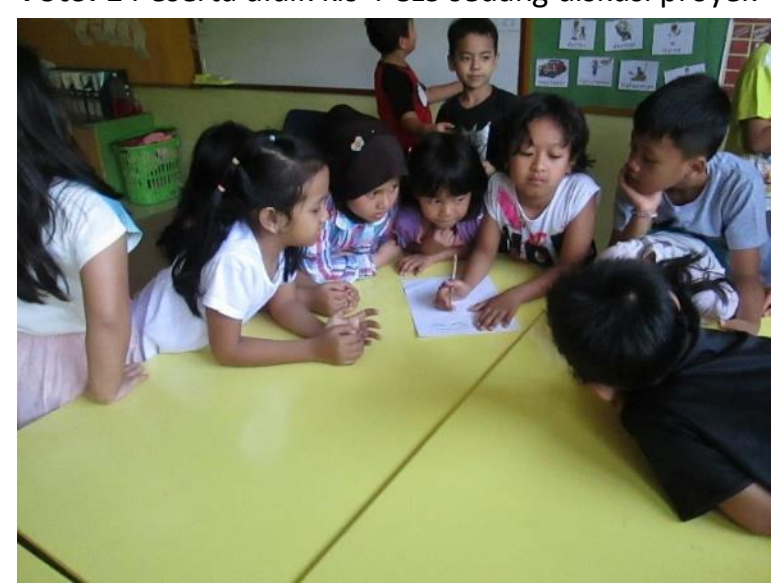

Pelaksanaan, Penanaman nilai-nilai karakter bagi peserta didik di CLS tidak mungkin diajarkan dalam bentuk penyampaian materi secara informatif dengan hasil penguasaan kognitif melainkan harus membekas kedalam jasmani dan ruhaninya sebagai manusia. Dengan demikian, segenap komponen CLS harus memastikan adanya program pendidikan dan pengajaran serta pembudayaan dalam bentuk pembiasaan-pembiasaan yang dilakukan oleh seluruh warga sekolah, tidak hanya guru, agar kondisi tercipta dan kondusif bagi tertanamnya niali-nilai leadership 4H. Pembiasaan-pembiasaan yang dilaksanakan di CLS adalah meliputi bagaimana peserta didik berfikir dan bertindak dengan berorientasi kepada indikator pencapaian dalam leadership $4 H$. 
Dengan demikian, berdasarkan uraian di atas nampaknya bahwa dengan menumbuhkembangkan karakter leadership $4 H$ pada diri peserta didik maka keseluruhan diri yang terkait dengan kebutuhan jiwa dan raga peserta didik akan terpenuhi. Keteladan dan pembiasaan merupakan kunci bagi lembaga pendidikan untuk menjadikan pendekatan ini berjalan dalam satu kesatuan dalam sebuah pendidikan dan pengajaran. Leadership $4 H$ tidak dapat diajarkan begitu saja kepada para peserta didik melainkan harus diaplikasikan oleh guru dan semua warga sekolah sebagai budaya hidup sehingga akan dicontoh dan diyakini oleh semua yang terlibat didalamnya dan menjadi acuan bagi masyarakat di sekitarnya.

Evaluasi,Dalam pelaksanaan evaluasi, secara umum, dalam evaluasi pencapaian kemampuan akademik memiliki kesamaan dengan sekolah lain pada umumnya, seperti ulangan harian, pemberian tugas terstruktur dan tidak terstruktur, ujian tengah semester, ujian akhir semester, dan seterusnya. Perbedaannya adalah dalam pelaksanaan dan bentuk serta cara evaluasi yang dilakukan. Setiap bentuk ujian tidak dipopulerkan sebuah sebuah kondisi yang membuat peserta didik merasa dalam suasana ujian. Kemudian, bentuk soal tidak selalu berbentuk yang baku seperti pilihan ganda, dan sebagainya, melainkan sering berupa proyek-proyek sederhana yang memicu kreatifitas peserta didik. Meski demikian, dalam pelaksanaan Ujian Nasional tetap harus mengikuti peraturan pemerintah sebagaimana mestinya. Selain itu peserta didik pun diharuskan melaksanakan evaluasi diri dari setiap mata pelajaran dengan mengisi formulir evaluasi diri (self-assessment) untuk menjelaskan daya serap mereka serta pendapat atau komentar mereka mengenai pelajaran yang sudah diikuti (Omar, 2011). Hasil ini akan dijadikan laporan portofolio untuk disampaikan didiskusikan bersama orang tua peserta didik dan guru terkait untuk langkah lanjutan.

Kemudian mengenai evaluasi perkembangan pencapaian kemampuan Leadership $4 H$ dari masingmasing siswa, sekolah membuat kebijakan dengan memaklumatkan penilaian yang dilakukan oleh seluruh guru setiap hari dengan mengamati leadership skills yang difokuskan pada setiap term. Hasil penilaian tersebut akan dilaporkan kepada guru kelas untuk dianalisis dan diambil kesimpulan dan dibuatkan laporan perkembangan secara tertulis.

Bagi guru, evaluasi dilakukan dengan teknik pengukuran performa kinerja (appraisal) secara bertahap dan menyeluruh serta berorientasi kepada pemeliharaan dan pengembangan sumber daya manusia. Para guru merasa diberikan ruang gerak yang lebih fleksibel dalam mengembangkan kemampuan dirinya. Meskipun demikian, tidak menutup kemungkinan adanya ketidakpuasan dari guru dengan penggunaan pendekatan yang dilakukan. Terlebih lagi bagi guru yang memiliki perbedaan ekspektasi dan orientasi serta harapan-harapan pribadi (Amy, 2011).

Penanggulangan Hambatan dan Penguatan Dukungan, Sebagaimana penjelasan yang sudah dikemukakan pada temuan penelitian mengenai faktor penghambat dan faktor pendukung, dalam hal ini peneliti tidak akan secara detil mengemukakan kembali melainkan akan langsung mengemukakan solusi yang memungkinkan untuk diambil oleh SD Cendekia Leadership School.

Tidak adanya Unit penelitian dan Pengembangan Kurikulum akan sangat menyulitkan langkah sekolah untuk mengelola secara umum program-program pendidikan. Setidaknya harus ada langkah untuk menunjuk seorang guru senior untuk mengendalikan ini dalam upaya membantu bidang akademik (School Academic Manager) dan Kepala Sekolah (manager). Hal ini bertujuan untuk mengawal serta mengawasi keseluruhan rencana, implementasi, dan evaluasi secara meneluruh guna mencapai hasil yang optimal.

Peningkatan pergantian guru (turn over) menunjukkan adanya kondisi yang belum aman dan nyaman bagi guru dalam melaksanakan tugas mereka. Dengan demikian, pemeliharaan sumber daya, khususnya jaminan kesejahteraan yang meliputi beragam aspek harus dilakukan oleh pihak sekolah dan 
yayasan. Kesejahteraan tidak selalu dalam bentuk uang, misalnya gaji tinggi saja melainkan segala aspek yang diberikan secara bertahap dan sesuai dengan tingkat kenyamanan guru. Tentunya perlu bantuan psikolog dan kecermatan para pimpinan untuk menemukannya.

Sebagian peserta didik sebagai subyek didik akan tergolong pula sebagai penghambat. Hal ini sangat tergantung kepada tujuan yang ingin dicapai oleh sekolah dari peserta didik. Artinya target keluaran (output) yang ingin dicapai harus seimbang dengan masukan (input). SD CLS memiliki tujuan pendidikan yang lebih menekankan kepada kualitas akhlak manusia, dengan demikian hendaknya mempersiapkan sistem yang dapat mengakomodasi beragam siswa dengan beragam karakter dan latar belakang keluarga (Thomas, 2015). Sehingga peserta didik tidak akan lagi dianggap sebagai bagian dari faktor penghambat dalam proses pendidikan di SD CLS.

Dalam pengamatan penelitian, sebagian orang tua peserta didik masih dianggap sebagai bagian dari faktor penghambat, dimana ditemukan indikasi terdapat sebagian orang tua yang dianggap kurang atau tidak menunjukkan kerjasama dan membantu proses pendidikan putra-putrinya. Dalam kaitan dengan ini pihak sekolah hendaknya lebih aktif untuk melakukan inisiasi untuk terciptanya hubungan yang lebih produktif. Langkah sosialisasi pun harus lebih diutamakan untuk memberikan pemahaman bagi orang tua sehingga mereka merasa terpanggil dan berkewajiban untuk berpartisipasi aktif dalam proses pendidikan di SD CLS.

Hasil Pencapaian Pendidikan Karakter, Untuk menjelaskan hasil-hasil yang dicapai dalam pendidikan dan pengajaran di SD Cendekia Ledership School dengan berbasis kepada Leadership 4H, peneliti melakukan pengamatan harian dengan memantau seluruh kegiatan dari pagi, saat kedatangan peserta didik di lingkungan sekolah serta sore hari saat siswa meninggalkan sekolah. Selain itu, peneliti menyiapkan dan menyebarkan angket sebanyak 100 angket yang dengan responden terdiri dari para orang tua peserta didik, baik yang sudah lulus maupun yang masih aktif sebagai peserta didik di SD Cendekia Leadership School. Hasilnya, ternyata sebagian besar orang tua peserta didik merasa sangat puas dengan hasil pendidikan dan pengajaran yang difasilitasi oleh SD CLS. Beberapa hal yang dapat dicatat dari hasil-hasil tersebut adalah sebagai berikut:

1. Budaya senyum, salam, sapa sudah membudaya di kalangan warga sekolah.

2. Budaya kebersihan diri, sekolah, dan lingkungan sekolah sudah membudaya dengan gerakan kebersihan yang didukung oleh seluruh warga sekolah dengan teknik 3M sampah.

3. SD CLS termasuk sekolah yang ramah dan jauh dari bullying dan tindakan kekerasan lainnya.

4. KBM dilakukan dengan pendekatan yang pendekatan individual, demokratis sehingga para peserta didik dapat menyesuaikan diri dengan lingkungan, merasa nyaman dalam mengekspresikan potensi dirinya.

5. Program kegiatan diorientasikan kepada kebutuhan para peserta didik.

6. Program inklusif yang memfasilitasi ABK (anak berkebutuhan khusus) yang dikelola secara inklusi menumbuhkan semangat kepedulian, saling berbagi, serta saling menghormati dan menghargai diantara warga sekolah khususnya para peserta didik.

Meski demikian, ini bukan berarti bahwa SD CLS sudah mencapai hasil secara keseluruhan. Masih banyak ditemukan kekurangan dan hambatan yang ditemukan peneliti selama penelitian, baik yang menyangkut persoalan manajemen pendidik dan tenaga kependidkan, karyawan, serta manajemen yang berkonsentrasi kepada pelayanan dan pengembangan peserta didik itu sendiri.

Uji Validitas Untuk memperoleh data yang akurat dan meyakinkan dari keseluruhan penelitian, maka peneliti melakukan uji validitas dengan cara memastikan kembali data-data dokumentasi, serta mengadakan diskusi-diskusi dengan beberapa guru dan para manajer untuk mendapatkan informasi, 
kritik, masukan serta harapan sehingga data-data empiris selama proses penelitian ini kredibel dan dapat menjadi acuan yang tetap bagi keperluan evaluasi dan penelitian selanjutnya. Langkah awal yang dilakukan adalah dengan membuat janji ulang untuk diskusi baik dilakukan empat mata maupun dalam konferensi kecil dengan beberapa guru senior, guru kelas yang dijadikan sampel, yakni guru kelas 3 dan kelas 4, beberapa dari peserta didik, terutama presiden siswa dan rekan-rekannya, juga beberapa orang tua yang secara tidak sengaja bertemu di area parkir atau di area jemputan.

Hasil dari uji validitas ini menghasilkan beberapa masukan positif berupa dukungan dan kepuasan, saran, juga kritik, yang dikemukakan sebagai berikut:

1. Pendidikan dan pengajaran yang dilakukan oleh para guru di CLS cukup memuaskan, Para orang tua peserta didik menilai bahwa para guru CLS sudah melayani putra putri mereka dengan hati sehingga hasilnya menjadikan para peserta didik menjadi, mandiri, tanggungjawab, menghargai perbedaan, dan lain-lain.

2. Sering ditemukan guru yang anti kritik serta menutup diri dari masukan orang tua peserta didik. Ditemukan pula bahwa pengaturan reward yang disebut Cendekia Award untuk penghargaan Leadership agar dikelola dengan lebih baik.

3. Sistem manajemen harus dibenahi untuk kelancaran dan ketercapaian indikator leadership $4 H$

4. Guru harus lebih sering diberikan pelatihan dan pemahaman mengenai budaya pendidikan di CLS terutama mengenai pendekatan Leadership $4 H$.

5. Perlu dipikirkan dan dirancang deskriptor dari khalifah fil Ard kaitannya dengan indikator Leadership $4 H$ agar ada kesesuaian antara indikator Leadership $4 H$ dengan visi CLS.

6. Perlu segera dibentuk tim pengembang kurikulum dan aplikasi pendekatan Leadership $4 H$ untuk keperluan pengawasan, pengendalian mutu, dan evaluasi.

7. Disepakati bahwa penelitian ini untuk tujuan evaluasi kedalam dan bukan untuk dipublikasikan.

8. Konsep "membela diri" dan "melindungi diri" dalam pergaulan siswa perlu dijelaskan dengan benar dan proporsional serta disosialisasikan terkait dengan beberapa kasus gangguan atau "bullying" yang beberapa kali terjadi di lingkungan CLS.

\section{Pendidikan Karakter, Kepemimpinan (Leadership), dan Proyeksi Pembinaan Peserta didik di Masa Perubahan}

Fenomena yang terjadi dan persoalan yang ditemukan dalam penelitian di SD CLS mengenai manajemen pendidikan karakter tentunya hanya sebuah contoh kecil yang dapat diungkapkan. Meski demikian, hal ini merupakan salah satu mata rantai dari keseluruhan manajemen pendidikan karakter yang harus menjadi perhatian bagi seluruh elemen bangsa Indonesia demi mempersiapkan sebuah generasi baru yang berkualitas dan siap menghadapi masa mereka di era perubahan. Beberapa hal yang akan dikemukakan terkait persoalan pendidikan karakter dari sudut pandang keseluruhan kepentingan bangsa Indonesia.

Tantangan, Pendidikan karakter pada hakikatnya adalah proses pendidikan penyadaran terhadap ruh atau mental manusia sehingga ia akan menyadari dirinya sebagai sesatu yang bernilai yang harus dihargai, memiliki integritas, berilmu pengetahuan dan keterampilan sehingga ia mampu bersosialisasi dengan lingkungannya serta secara sadar ia pun mengenal Allah SWT sebagai satu-satunya yang paling sah untuk menjadi tempat berorientasi dari semua hal yang ia lakukan dan jalani dalam kehidupannya. Iman harus memandu perilaku semua manusia termasuk pimpinan sekolah atau kepala sekolah (Irawan, 2019b). Namun demikian, persoalan pendidikan karakter dalam prosesnya lebih sulit dari proses pengajaran atau pelatihan kemampuan-kemampuan yang besifat kecakapan fisik, seperti belajar berjalan, 
belajar mengendarai sepeda motor atau mobil, atau belajar salah satu bahasa asing. Belajar bahasa Inggris masih dapat diupayakan dengan hasil mahir pada saat peserta didik menginjak semester tujuh perguruan tinggi atau bahkan lebih, tetapi mengajarkan kejujuran yang dilakukan pada waktu yang sama dengan masa yang disebutkan di atas tentunya akan sangat sulit bahkan kemungkinan besar tidak akan bisa dicapai.

Kepemimpinan merupakan salah satu faktor penting yang harus diperhatikan dan disiapkan demi keberlanjutan pendidikan nilai dari generasi ke generasi. Di dalam kepemimpinan semata-mata tidak berfokus kepada pencapaian seseorang untuk menjadi atau menduduki posisi pemimpin melainkan bagaimana seseorang memahami dan membudayakan nilai-nilai dan sikap kepemimpinan dalam dirinya. Setiap orang yang memahami nilai-nilai kepemimpinan akan menjadikan dirinya mampu berada dalam berbagai posisi baik ketika memimpin maupun memimpin. Alasan mengapa kepemimpinan dianggap penting karena, pertama; kepemimpinan pada dasarnya fitrah manusia sebagaimana tertulis dalam Al Quran: Al Baqarah: 30, bahwa Allah SWT menciptakan manusia sebagai pemimpin di bumi (khalifah fil Ard). Kedua, kepemimpinan mengandung unsur kecerdasan dan kecakapan manajemen, kecakapan hidup, keteguhan iman dan kesabaran, kearifan, kreatif dan produktif, serta kekuatan dan kesehatan.

Para orang tua dan guru adalah pembimbing dan fasilitator dalam pendidikan karakter. Seorang pembimbing dan fasilitator tentunya harus mampu menjadi figur yang baik bagi peserta didik yang akan menjadikan orang tua dan guru sebagai teladan dan panutan bagi mereka. Dengan demikian, orang tua dan guru harus benar-benar terlebih dahulu memahami dan menjadikan nilai-nilai karakter itu menjadi pakaian diri mereka agar dapat dicontoh dan diteladani.

Pendidikan karakter sangat tepat dilakukan sejak usia dini bahkan menurut para ahli dari sejak masa dalam kandungan ibu (dalam rahim). Selain itu, peran orang tua sebagai orang dewasa yang pertama kali dikenal oleh calon peserta didik sangatmenentukan untuk menjadi model dan figur yang positif dalam penanaman nilai-nilai karakter atau akhlak yang baik. Dengan demikian, ini menjadi tantangan besar bagi setiap generasi untuk mempersiapkan diri menjadi calon orang tua yang akan mewariskan karakter positif, dan ini akan berlaku di seluruh lingkungan pendidikan, yakni keluarga, sekolah, dan masyarakat. Ketiga lingkungan pendidikan harus memiliki semangat, kerja cerdas dan kerja keras yang seimbang serta saling mendukung dan menguatkan karena ketidakseimbangan yang membuat peserta didik menjadi bingung, tidak mengerti, sehingga mereka akan kehilangan kepercayaan serta frustrasi terhadap pendidikan, orang dewasa, dan nilai-nilai karakter positif tersebut (Hasyim, 2015). Kerjasama yang baik, saling mendukung, lingkungan yang kondusif serta tersedianya konsep yang sistematis dan praktis yang diaplikasikan sehingga menjadi budaya keseharian sangat memungkinkan tertanamnya nilai-nilai karakter pada setiap generasi. Satu hal yang sangat penting untuk mengawal keberhasilan ini adalah pengawasan dan evaluasi yang dilaksanakan secara teratur dan terukur.

Hambatan, Bangsa Indonesia pada dasarnya sudah memiliki nilai-nilai karakter positif yang lahir dari budaya, agama, serta adat istiadat turun temurun yang diwariskan dari nenek moyang bangsa Indonesia berupa ajaran moral yang teraplikasi kedalam bentuk kearifan lokal. Demikian pula dengan agama, dimana beberapa agama sudah menghiasi khazanah kebangsaan Indonesia yang kesemuanya mengajarkan nilai-nilai moral yang positif baik dalam agama itu didalam agama itu sendiri, umat beragama, dan antar umat beragama. Berdasarkan hal ini, seharusnya bangsa Indonesia merupakan bangsa yang menjadi model negara yang paling berkarakter dalam segala hal, terlebih lagi mengenai kemajuan bangsa dalam bidang Ilmu pengetahuan dan teknologi karena pendidikan karakter akan menjadi penggerak bagi manusia untuk mencintai dan menguasai ilmu pengetahuan dan teknologi yang bijak tentunya. Namun demikian, beberapa hal menjadi penghambat bagi bangsa Indonesia untuk menjadi 
negara yang benar-benar menjadi bangsa yang berkarakter, diantaranya adalah: Pertama, derasnya arus globalisasi, akulturasi budaya, serta persilangan pemahaman budaya (cross cultural understanding) yang tidak diantisipasi oleh kesiapan bangsa Indonesia untuk menghadapi kehadirannya, menjadikan bangsa Indonesia terseret kedalam kondisi kehilangan jati diri dan kebanggaan sebagai bangsa Indonesia. Begitu pula para pemuda Indonesia, mereka cenderung lebih membanggakan budaya bangsa lain dibanding bangsanya sendiri. Hal ini dapat terlihat dari perilaku dan kegiatan, serta peminatan yang mereka pilih dan sukai. Misalnya, perlu dilakukan penelitian mengenai perbandingan minat pemuda Indonesia terhadap seni bela diri Indonesia (silat) dan bela diri bangsa lain. Secara otomatis, generasi berikutnya akan bercermin kepada generasi sebelumnya dengan kondisi sebagaimana dijelaskan di atas. Kedua, meski sistem pendidikan di Indonesia sudah didukung dengan undang-undang dan kebijakan yang berorientasi kepada nilai luhur keagamaan dan budaya bangsa Indonesia namun dalam implementasinya belum menunjukkan proses yang menggembirakan.

Proyeksi ke Masa Depan, Dari keseluruhan hasil penelitian dapat diambil sebuah rekomendasi dan harapan berupa proyeksi ke masa yang akan datang dimana bangsa Indonesia melalui semua lingkungan pendidikan, baik di rumah, di sekolah, dan di masyarakat harus bahu membahu bersama-sama mewujudkan masyarakat Indonesia yang memiliki iman yang kuat, budi pekerti yang luhur, cerdas, dan terampil yang membudaya dalam kehidupan sehari-hari yang berkelanjutan. Proyeksi tersebut adalah:

1. Memberikan pemahaman dan pendidikan bagi calon orang tua untuk menyiapkan generasi yang cerdas, sholeh, pandai, sehat, dan sejahtera

2. Memberikan pemahaman dan pendidikan kepada para orang tua untuk memberikan dan mendukung pendidikan yang berkualitas.

3. Mengutamakan dan mengoptimalkan pendidikan karakter di sekolah-sekolah sebagai ruh dari proses dan hasil pendidikan dan pengajaran.

4. Perlu dirancang program-program yang kreatif dan dinamis yang mampu diaplikasikan pada peserta didik pada masa perubahan dengan keadaan teknologi yang semakin maju.

Dengan demikian, peneliti berharap bahwa hasil-hasil penelitian ini tidak hanya bermanfaat bagi SD CLS sebagai bahan evaluasi melainkan dapat menjadi inspirasi dan acuan bagi implementasi manajemen pendidikan karakter di semua sekolah di Indonesia

\section{SIMPULAN}

SD Cendekia Leadership Sshool sudah melakukan langkah-langkah perencanaan yang lengkap dan sistematis yang menghasilkan rumusan-rumusan rencana pendidikan dan pengajaran yang selanjutnya dijadikan acuan pelaksanaan kegiatan pendidikan karakter dan pengajaran yang berbasis Leadership 4H. Terdapat proses pengorganisasian yang disusun secara lengkap dan terperinci mengenai posisi, tugas, tanggungjawab serta mekanisme kerja yang diatur melalui Prosedur Operasi Standar (Standard Operating Procedure). Meski terdapat nomenklatur yang tidak umum dalam penentuan posisi General Manager dalam sebuah Yayasan Pendidikan. Secara keseluruhan pelaksanaan pendidikan karakter dengan berbasis Leadership $4 \mathrm{H}$ sudah sejalan dengan perencanaan yang ditentukan dan disepakati di awal. Dalam prosesnya pun terdapat pengawasan untuk memastikan bahwa proses pelaksanaan berjalan dengan baik dan tepat. Proses pelaksanaan ini dilakukan secara bertahap dengan tujuan untuk memastikan ketercapaian setiap rencana dalam pelaksanaan secara optimal. Evaluasi diberlakukan bagi seluruh warga sekolah, terutama guru dan peserta didik. Bagi para peserta didik, evaluasi dilaksanakan untuk mengukur ketercapaian akademik serta perkembangan karakter yang dituangkan dalam indikator pencapaian pendidikan karakter dalam Leadership $4 \mathrm{H}$. Selain itu, guru sebagai teladan dievaluasi kinerjanya untuk 
memastikan bahwa pendidikan karakter dapat membudaya secara baik di lingkungan CLS. Beberapa hambatan dan peluang selalu muncul selama implementasi pengelolaan pendidikan sebagaimana telah diuraikan sebelumnya. SD CLS terus melakukan perbaikan-perbaikan melalui tindak lanjut dari hasil evaluasi secara keseluruhan serta mengimbanginya dengan pemanfaatan peluang-peluang yang dimiliki dan dijumpai selama proses implementasi termasuk mengerahkan beberapa daya dukung yang ada. Secara keseluruhan dalam penelitian ditemukan hasil yang menunjukkan bahwa pendidikan karakter dengan berbasis pendekatan Leadership $4 \mathrm{H}$ dapat terlaksana dengan baik, meskipun masih banyak kekurangan-kekurangan yang ditemukan. Hasil ini berdasarkan hasil pengamatan yang dilakukan sebelum, selama, dan pasca penelitian, serta penyebaran angket tingkat kepuasan pelanggan kepada para orang tua siswa lulusan dan yang masih aktif terkait dengan pembudayaan karakter dalam Leadership 4H.

\section{DAFTAR PUSTAKA}

AA, F. P. dan S. (2011). Supervisi Pendidikan. Bandung: Refika Aditama.

Amy, C. (2011). Battle Hymn of The Tiger Mother. New York: The Penguin Press.

Arikunto Suahrsimi, A. J. S. (2014). Evaluasi Program Pendidikan. Jakarta: Bumi Aksara.

Badrudin. (2014). Manajemen Peserta Didik. Jakarta: Indeks.

Bayan, A. (2010). Shahih Bukhari Muslim. Bandung: Jabal.

Buckley, P. dan I. (2015). The Scientific Paradigm of Islamic Education Management: Phenomenology

Perspective. Jurnal Pendidikan Islam, 2(1).

Cresswell John W. (2014). Research Design; Pendekatan Kualitatif, Kuantitatif, dan Mixed. Yogyakarta:

Pustaka Pelajar.

Hasyim, S. (2015). Akhlak Tasawuf. Malang: Madani Medi.

Irawan. (2019). Filsafat Manajemen Pendidikan Islam. Bandung: Rosdakarya.

Irawan, ( ed ). (2019). Pengantar Wahyu Memandu Ilmu. Depok: RajaGrafindo.

Marzuki. (2015). Pendidikan Karakter Islam. Jakarta: Amzah.

Muhammad, F. (2015). Model-Model Pembelajaran Inovatif. Jogjakarta: Ar Ruzz Media.

Munif, C. (2010). Gurunya nausia. Jakarta: Kaifa.

Omar, H. (2011). Perencanaan Pengajaran Berdasarkan Pendekatan Sistem. Bandung: Bumi Aksara.

Terry, G. (2014). Prinsip-Prinsip Manajemen. Jakarta: Bumi Aksara.

Thomas, L. (2015). Charracter Matters. Jakarta: Bumi Aksara. 